References

Office for National Statistics and Teenage Pregnancy Unit. Health Statistics Quarterly 24, Winter 2004. London, UK: Office for National Statistics, 2005. http://www. statistics.gov.uk [Accessed 16 August 2005]

2 Social Exclusion Unit. Teenage Pregnancy. London, UK: HMSO, 1999.

3 Government White Paper. Choosing Health: Making Healthy Choices Easier. London, UK: Stationery Office, 2004; Chapter 3. http:// www.dh.gov.uk/PublicationsAndStatistics/Publications/Publications PolicyAndGuidance/PublicationsPolicyAndGuidanceArticle/fs/en? CONTENT_ID=4094550\&chk=aN5Cor [Accessed 16 August 2005].

4 Faculty of Public Health Medicine. http://www.fphm.org.uk.

5 Botting B, Rosato M, Wood R. Teenage mothers and the health of their children. Popul Trends 1998; 93: 19-28.

6 Biehal N, Clayden J, Stein M, Wade J. Moving On: Young People and Leaving Care Schemes. London, UK: HMSO, 1995.

7 Hobcraft J. Intergenerational and Life-course Transmission of Social Exclusion: Influences of Childhood Poverty, Family Disruption and Contact with the Police. CASE Paper 15. London, UK: London School of Economics, 1998

8 Kiernan K. Transition to Parenthood: Young Mothers, Young Fathers - Associated Factors and Later Life Experiences. Welfare State Programme, Discussion Paper WSP/113. London, UK: London School of Economics, 1995.

9 Wellings K, Nanchahal K, Macdowall W, McManus S, Erens R, et al. Sexual behaviour in Britain: early heterosexual experience. Lancet 2001; 358: 1843-1850.

10 Berthoud R. Teenage births to ethnic minority women. Popul Trends 2001; 104: 12-17.

11 RT Michael, JH Gagnon, EO Lauman, G Kolat. Sex in America. Boston, MA: Little Brown \& Co., 1994.

12 Ermisch J. Does a 'Teen-birth' have Longer-term Impacts on the Mother? Suggestive Evidence from the British Household Panel Study. Working Papers 2003-32. Colchester, UK: Institute for Social and Economic Research, November 2003. http://www.iser.essex.ac. uk/pubs/workpaps/pdf/2003-32.pdf [Accessed 16 August 2005].

13 Robson KL, Berthoud R. Early Motherhood and Disadvantage: A Comparison Between Ethnic Groups. Working Papers 2003-29. Colchester, UK: Institute for Social and Economic Research, October 2003. http://www.iser.essex.ac.uk/pubs/workpaps/pdf/2003-29.pdf [Accessed 16 August 2005]

14 Liao TF. Mental Health, Teenage Motherhood, and Age at First Birth Among British Women in the 1990s. Working Papers 2003-33. UK: Institute for Social and Economic Research, November 2003. http://www.iser.essex.ac.uk/pubs/workpaps/pdf/2003-33.pdf [Accessed 16 August 2005].
15 Wilson J. Maternity policy. Caroline: a case of a pregnant teenager Prof Care Mother Child 1995; 5: 139-142.

16 Dattani N. Mortality in Children Aged Under 4. London, UK: Office for National Statistics, 1999. http://www.statistics.gov.uk/articles/ hsq/HSQ2children.pdf [Accessed 16 August 2005].

17 Peckham S. Preventing unplanned teenage pregnancies. Public Health 1993; 107: 125-133.

18 Simms M, Smith C. Teenage mothers: late attenders at medical and ante-natal care. Midwife Health Visit Community Nurse 1984; 20: $192-200$

19 Foster K, Lader D, Cheeseborough S. Infant Feeding Survey 1995. London, UK: HMSO, 1997.

20 Pevalin DJ. Outcomes in Childhood and Adulthood by Mother's Age at Birth: Evidence from the 1970 British Cohort Study. Working Papers 2003-31. Colchester, UK: Institute for Social and Economic Research, October 2003. http://www.iser.essex.ac.uk/pubs/ workpaps/pdf/2003-31.pdf [Accessed 16 August 2005].

21 Kiernan K, Hobcraft J. Childhood Poverty, Early Motherhood, and Adult Social Exclusion. Analysis of Data from the 1958 UK Birth Cohort Study for the Social Exclusion Unit. CASE Paper 28. London, UK: London School of Economics, 1999.

22 Lawlor DA, Shaw M. Too much too young? Teenage pregnancy is not a public health problem. Int J Epidemiol 2002; 31: 552-554.

23 Wellings K, Nanchahal K, Macdowall W, McManus S, Erens R, et al. Sexual behaviour in Britain: early heterosexual experience. Lancet 2001; 358: 1843-1850.

24 British Market Research Bureau International. Evaluation of the Teenage Pregnancy Strategy. Tracking Survey. Report of Results of Benchmark Wave, January 2001. http://www.dfes.gov.uk/ teenagepregnancy/dsp_showDoc.cfm?FileName=final\%20tp $\% 20$ ben chmark\%2Epdf [Accessed 16 August 2005].

25 Emler N. Self-esteem: The Costs and Causes of Low Self-worth. York, UK: Joseph Rowntree Foundation, 2001. http://www.jrf.org.uk/ knowledge/findings/socialpolicy/pdf/N71.pdf [Accessed 16 August 2005]

26 Lawlor DA, Shaw M. Teenage pregnancy rates: high compared with where and when? J R Soc Med 2004; 97: 121-123.

27 Hoffman SD. Teenage childbearing is not so bad after all ... or is it? A review of the new literature. Fam Plann Perspect 1998; 30: $236-239,243$.

28 UNICEF Innocenti Research Centre. A League Table of Teenage Births in Rich Nations. UNICEF Innocenti Report Card No. 3, July 2001. Florence, Italy: UNICEF Innocenti Research Centre, 2001. http://www.unicef-icdc.org/publications/pdf/repcard3e.pdf [Accessed 16 August 2005].

\section{Journal Review}

Unintended pregnancies with etonogestrel implant (Implanon): a case series from postmarketing experience in Australia. Harrison-Woolrych M, Hill R. Contraception 2005; 71: 306-308

This is an observational study of the failures that have occurred with Implanon ${ }^{\circledR}$ in Australia since the launch of the product. The pregnancies were reported to the Australian reporting agency, the Adverse Drug Reactions Advisory Committee. Data were collected between 2001 and 2004 During this 3-year period an estimated 204486 Implanon devices were inserted, based on figures from the Australian Pharmaceutical Benefits Scheme, which subsidises the cost of Implanon. A total of 218 pregnancies were reported of which five were ectopic. The failures were categorised in seven groups: non-insertion (85), already pregnant (46), insufficient information collected (45), incorrect timing of fitting (19), drug interaction (8) and Implanon expelled (3). The authors acknowledge that there may have been underreporting of pregnancies and not all the Implanon devices issued may have been fitted.

Although the trials performed to support the licensing of Implanon showed a pregnancy rate of zero, these findings from early postmarketing experience suggest that there will be a small method failure rate with the product. This is the first publication that illustrates that there is a drug interaction. In this study all the reported instances were women taking anti-epileptic drugs. The data also show that we really have to make sure that Implanon devices are fitted correctly and that the woman has no risk of pregnancy before fitting.

So if errors at the time of insertion are taken out of the equation then the pregnancy risk with this method is still likely to be very small. The authors calculate it as somewhere in the region of 1 per 1000 . It is up to us as practitioners fitting the method to make sure that no unnecessary errors occur.

Reviewed by Judy Murty, DRCOG, MFFP SCMO Contraceptive and Sexual Services, Leeds, UK

The association of hysterectomy and menopause: a prospective cohort study. Farquhar CM, Sadler L, Harvey SA, Stewart AW. Br J Obstet Gynaecol 2005; 112: 956-962

Does hysterectomy with ovarian conservation lead to earlier loss of ovarian function (an early menopause) than might have been expected without surgery? This has been a controversial question for many years. The methodology of earlier studies, such as reliance on symptoms alone for the diagnosis of ovarian failure, was open to question and previous reports have been contradictory. This paper from New Zealand reports on a large, prospective, cohort study. Premenopausal women aged under 46 years undergoing hysterectomy for benign pathology and a matched cohort of volunteers who did not undergo hysterectomy were followed for up to 5 years with annual serum follicle-stimulating hormone (FSH) levels. The menopause was defined as having occurred once an FSH level of $\geq 40 \mathrm{IU} / \mathrm{l}$ was reached. This cut-off level was sufficiently high to make it unlikely that there would be a return to premenopausal values.

The results of the study suggest that women who had a hysterectomy were likely to reach the menopause almost 4 years earlier than women in the control group who had retained their uteri and who had no other interventions that might interfere with local blood supply or with ovulation. Unilateral oophorectomy at the time of hysterectomy increased the likelihood of an early menopause yet further. It is likely that disruption to the blood flow to the ovaries at the time of surgery affects ovarian function and ovarian reserve, leading to earlier ovarian failure.

Although this study has some limitations, the results do suggest a definite link between hysterectomy and early menopause with its associated health risks. This will now have to be discussed with premenopausal women who are considering a hysterectomy so that they can make choices most appropriate for themselves. The importance of offering alternatives to hysterectomy to women with benign gynaecological disorders is strengthened by this study.

Reviewed by Vibha Ruparelia, MRCOC

Specialist Registrar in Obstetrics and Gynaecology, Luton \& Dunstable Hospital NHS Trust, Luton, UK 